\title{
Regional Core Competence on the Basis of Small Scale Industries (SSIS): Case of Makassar City, Indonesia ${ }^{1}$
}

\author{
Palmarudi Mappigau \\ The Dapartment of Agribusines, Post Graduate Study Programs, \\ Hasanuddin University,Makassar,Indonesia \\ Haris Maupa \\ The Department of Management, Faculty of Economic and Business, \\ Hasanuddin University,Makassar,Indonesia \\ Email:rudipal@yahoo.com
}

\section{Doi:10.5901/mjss.2015.v6n2p215}

\begin{abstract}
The objective of this study was to propose the practical methods to apply core competencies concept in small scale industries (SSIs) for determination regional core competence of the Makassar City. Two groups of samples respondent consisting of 12 experts and 20 entrepreneurs of owners SSIS selected by purposive sampling method. The data were collected through survey techniques and two series of focus group discussion (FGD), then analyzed using identification, matrix ranking, tree diagram and expected value, value chain, regional core competence, and SWOT. The result of the case study and FGD shows that the core competence of the core product (i.e. passion fruit juice products) was distinctive aroma and flavor and medical content which identified in the operating activities. The core competence of SSIs determined as regional core competence of Makassar City. To develop of the regional core competencies recommended several strategies priority, such as developing human resources abilities of farmers and entrepreneurs, building information and knowledge sharing between the entrepreneurs with farmers and traders, building cooperation with universities, and improving a business environment that is conducive to SSIs. The implication of this study is that this will contribute to the theory by providing practical methods to apply the concept of core competencies in regional development. This study also offer practical and social implications, such as strenghtenig competitive advantage and profitability of SSIs, improving the region's economy and competetitiveness, and and finally be able to assist in the alleviation of poverty in the region.
\end{abstract}

Keywords:Superior product, core product, core competence, regional core competence, small scale industries

\section{Introduction}

A major challenge faced in the development of the economy for many developing countries, particularly Indonesia is still low competitiveness of the industry in the international market and regional disparities. In order to overcome these challenges, the government of Indonesia has set the two approaches in developing national industry. The first is topdown approach, a planned industrial development of the central government (by design) and followed by the participation of local government to determine priorities (35 priority industries, the cluster approach). The second is bottom-up through the identification and development of regional core competence, which is the competitive advantage of a region (district or city) based on its excellence and uniqueness.

Small scale industries (SSIs) are of crucial importance for regional economics of many cities in Indonesia, like Makassar. According to data from the Industry and Trade Department of Makassar City, in 2012 there are 4.724 unit SSIs operating in Makassar City, they provide job opportunities for 34260 people, and contributed the second largest GDP after the trade sector which amounted to $20.74 \%$. In connection with the potential resources of SSIs, Laosirihongthong (2011) argued that despite the growing salience of SSIs, little research looks into the intangible resources that these industries deploy to thrive, especially with respect to core competence.

The core competence concept has agreed in strategic management research for the past twenty years as key component in building organization competitive advantage, include SSIs (Jardón, 2011; Ljungquist, 2012, Ghannad and Ljungquist, 2012). However, the core competence concept does not seem to be fully developed in building regional

\footnotetext{
1 The paper presented at the 28th International Business Research Conference held Barcelona, Spain on 8 - 9 September, 2014
} 
competitiveness. Much previous research of regional competitiveness focused on factors that contributed to regional competitiveness, such productivity and regional variables (Boddy et al., 2005). An additional gap in research has also been identified by Garden and Martin (2005) who provided an overview of the main factors explaining regional competitiveness, and they concluded that human knowledge and innovation, and technological specialization are attributes which are important for regional competitiveness. Moreover, human knowledge and innovation, and technological specialization are well known as a core competence (Torkkeli and Markku, 2002; and Jardon, 2011). It was obviously seen that there was no study done on utilization of local resources and capability of a region, such as distinctive competence owned SSIs to build the regional competitiveness through development of the regional core competence. The distinctive or core competence has been recognized by many researchers and practitioners as a key component in building an organization's competitiveness. Therefore, Therefore, the research question was how to identify and determine core competence of SSIs and how to determine regional core competence of Makassar City through core competence of SSis and how to formulate alternative strategies for developing the regional core competence in order to improve regional competitiveness of the city.

\section{Objective}

The objective of this study was to propose the practical methods to apply core competencies concept in SSIs for determination regional core competence

\section{Review Literature}

Small scale industries (SSIS) in developing countries have the unique feature such as labor-intensive manufacturing methods, equipment is often secondhand, and they are more efficient than cottage industry but less efficient than large-scale industries and they are concentrated in urban areas and villages (Benavides, 1992). According to Hussain (2003), definition of SSIs varies from one country to the other. For example in India, SSIs are defined based on their investment in plant and machinery, is where the investment in plant and machinery does not exceed twentyfive lakh rupees and in Malaysia, SSIs defined based on their employee and investment, they have number employee between 5 - 50 or their investment less than RM 250.000. In Indonesia context, industry defined as an economic activity that manufacturing raw materials, and semi-finished products into products with a higher value to the end user, including the activities of design and engineering industry, and SSIs defined as industry that have infestation does not exceed IDR 200.000 excluding buildings and land business premises.

SSIs are of crucial importance for regional economics. Mansour Hefnawy (2006) states that three main issues relevant to the roles SSIs to promote effective socio-economic development within a region, namely: (1) the ability of SSIs to drive the chain of economic added value at regional levels; (2) the capability of SSIs to provide job opportunities within the region; and (3) the capability of SSIs to generate income convergence and more regional equality. Constantin (2002) argues that the importance of SSis to regional development derives from their ability to innovate, their contribute to the creation of wealth, employment, and income generation both in rural and urban areas, thus, ensuring a more equitable income distribution, and their contribution to the performance of less developed regions and their role in the revitalization of certain industrial regions. Shihabudheen (2013) states that SSIs not only play crucial role in providing large employment opportunities at comparatively lower capital cost than large industries but also help in industrialization of backward areas, thereby, reducing regional imbalances, assuring more equitable distribution of national income and wealth. In emphasizing the importance of SSIs for regional development, Mitrut and Contantin (2006) states that SSIs diminish the regional consequences of privatization and/or restructuring for regional development, and they can represent an important source of local and regional dynamism and, thus, a source for economic and social cohesion.

The SSIs are not simply smaller versions of large industries, since they lack the size and diverse tangible resources that large industries possess, especially in the capital and technology intensive industries. SSIs lack the advantage of massive resources when they engage in the competitive market. Instead, they have intangible resources comprises a collection of industry specific capabilities that are not easily duplicated by rival industries (Laosirihongthong, 2011). A number of views on sources of distinctive competence of SSIs, Sweeney (1981) mentioned that distinctive competence of the SSIs is the primary source for entrepreneurship and innovation in the economy. Stoner (1987) on the other hand, point out that the key distinctive competence of SSIs is the experience, knowledge and skills of the owners and workers. Lai-Yu (2001) explores the distinctiveness of SSis, concluding that entrepreneurship and a simple capital structure are their key assets; entrepreneurship, because it is inherently inimitable; and a simple capital structure, 
because a lack of investment in specialised assets allows quick responses to change. According to Yamoah (2013), for a business to develop and sustain a competitive advantage, it must have some sort of competitive advantage, based on a distinctive competency, which enables it to produce a unique value proposition. Kostopoulos et al. (2011) argued that distinctive competence is directed related to the resource based view (RBV).

The concept of core competencies also evolved from RBV of the firm (Srivastava, 2005). Yamoah (2013) argued that resource-based view suggests that the source of competitive advantage is rooted in a firm's resources and capabilities. Resources include capital equipment, skills of individual employees, reputation, and brand names. Capabilities, on the other hand, refer to a company's skill at effectively coordinating its resources. In other words, resources are the source of a company's capabilities; and capabilities refer to a company's ability to bring these resources together and to deploy them advantageously. Capabilities also differ from resources in that they cannot be given a monetary value, as can tangible plant and equipment, and are so deeply embedded in the organizational routines and practices that they cannot be easily imitated. Naylor (2001) mentioned two definition of core competence. First, core competencies as aggregates of capabilities, where synergy is created that has sustainable value and broad applicability. That synergy needs to be sustained in the face of potential competition and, as in the case of engines, must not be specific to one product or market. So according to this definition, core competencies are harmonized, intentional constructions. Second, core competence is a combination of complementary skills and knowledge bases embedded in a group or team that results in the ability to execute one or more critical processes to a world class standard. Two ideas are especially important here. The skills or knowledge must be complementary, and taken together they should make it possible to provide a superior product. On the other hand, Cyrus and Moghaddam (2011) provided four definitions for core competencies, they are: (a) the collective learning in the organization, especially how to coordinate diverse production skills and integrated multiple streams of technologies; (b) intangible or the bundling of intangible assets, which cannot be easily duplicated by competitors; however they also would be difficult to replace if destroyed or damaged; (c) a unique combination of technologies, knowledge and skills that possessed by one company in the market.

Liu and Tian (2012) argued that the core competence is the important power to help enterprises to grow, which is the long-term competitive advantage and the basic to realize sustainable development foundation. The core competence is the ability that an enterprise can gain competitive advantage for a long-term, is the peculiar, withstand the test of time, have ductility and is difficult to the rival to imitate the technology or ability for the enterprise. Prahalad dan Hamel (1990) suggested three factors are important to identify core competencies in any firms and business : (a) provides potential access to a wide variety of markets; (b) makes a significant contribution to the perceived customer benefits of the end product; and (c) difficult for competitors to imitate. Naylor (2001) mentioned that the characteristics of core competencies are they provide a set of unifying principles for the organization and they are pervasive in all strategies, they provide access to a variety of markets., they are critical in producing end products, and they are rare or difficult to imitate. Andriessen et al. (2000) emphasized that core competence are determined by a combination of intangible assets such as knowledge and skills, standards and values, explicit know-how and technology, management processes and assets and endowments such as image, relationships, and networks

\section{Methodology}

This type of study is a qualitative descriptive case study approach, that focused on the issue of the SSI's core competence and regional core competence in Makassar City,Indonesia. Sampling technique to determine respondents sample of two target groups population are conducted with purposive sampling. The first one is experts and the second one is the entrepreneurs of SSIs. The number of expert is 12 actors, i.e, 6 actors in each academics and local government staffs who selected according to their expertise in regional development, small scale industry, and core competences. Thus, the number of the entrepreneurs sample is 20 firm owners of the SSIs who selected according to their products categorized as superior products

Data collected through structured interviews with tools questionnaires, and unstructured interview with two series forum group discussions (FGD). Questionnaires based on Likert 5 point scale, with 1 as unimportant and 5 as most important. A six-step analysis methods employed in this study. First, identification analysis to select potential of SSIs from all existing SSIs in Makassar City and the potential of the SSIs are those that have been promoted by the government to be developed. Second, matrix ranking analysis to select five highe'st ranking as a superior product from the potenstial SSIs in the Makassar City. Selecting the five hinghe'st ranking based on criteria the average sales and profits growths for the past five years, market orientated, number of employee, and raw materials supported locally. Third, the model analysis of TEV (tree diagram ad expected value) to identify ranking of indicators for selecting core product from the five superior products. The TEV analysis in this study uses the analysis model developed by Suharso 
(2008) by way of integrating the delphi method, decision tree, and expected values. Calculations carried out using the Statistical Package for Social Sciences (SPSS) version 16.0 and Microsoft Excel 2007 Software to measure weight value of all the indicators. Results calculation of the weight value of the indicator used to determine the priority indicators of core product. Fourth, value chain activity analysis (Porter, 2011) to identify and find core competence of SSis along the value chain of core product.Fitth, regional core competence analysis (Ministry of Industry,2010 and Djamaris, 2007) to determine whether the core competence of the SSis is frasible to be regional core competence of the Makassar City. Sixth, SWOT (strengths, weaknesses, opportunities, and threats) analysis (Porter, 1979) to select priorities of strategy for developing the regional core competence. According to Min Wu et al. (2013), use of a combination of the Delphi method, fuzzy and SWOT analyst is a make better decisions in assigning feasible strategies. Framework methodology to determine regional core competence is presented on Figure. 1.

Figure 1. Framework Methology To Determine Regional Core Competence

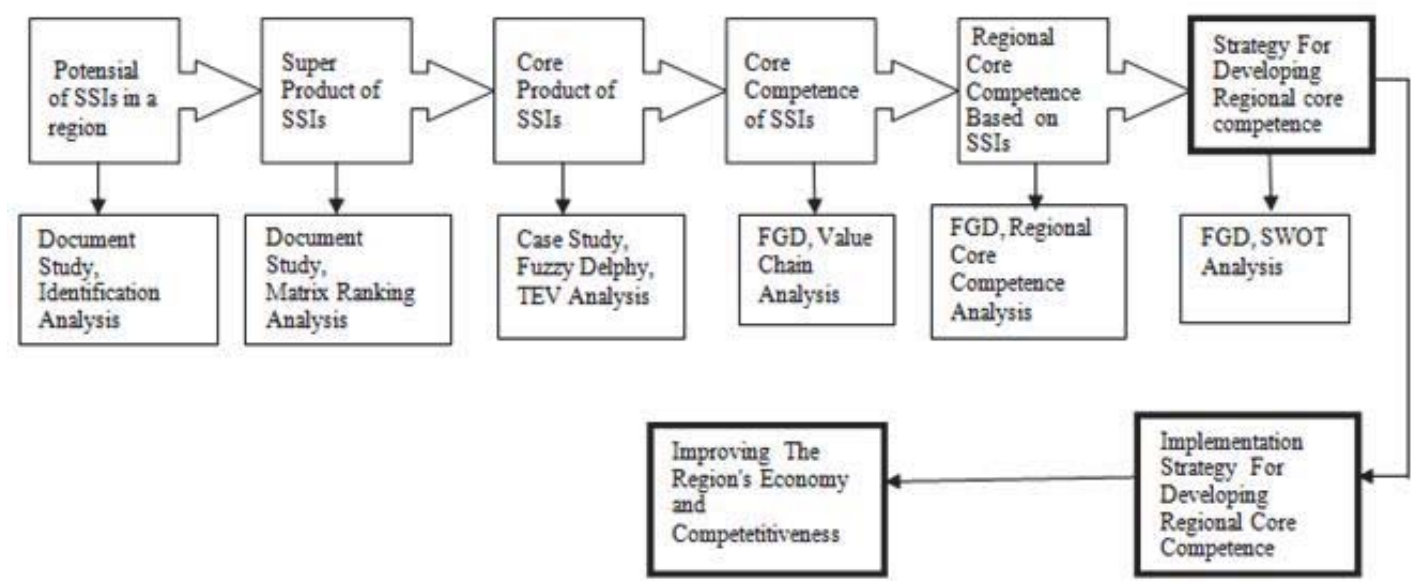

Source: Mappigau and Maupa (2012)

\section{Result and Discussion}

Result of matrix ranking analysis suggest that there were five products which established as superior products from all potential products in the existing SSIs at Makassar City. All of them are agricultural base small scale industries, i.e passion fruit juice product, noodle product, cowhide leather product, furniture product, and frozen shrimp and fish product. Further, selection indicators for establishing a core product from the five superior products analyzed by TEV based on fuzzy delphy methods, which involved judgment of the two target group respondens, namely experts and entrepreneurs of SSIs. The respondents given a questionnaire separately in order to obtain their opinions about the decision tree from the ranks of the second level (dimensions) and so on until reaching the ranks of the operational level (indicators). After the whole questionnaires collected, four experts and two entrepreneurs are invited into a closed meeting. Agenda of the close meeting was giving judgement about importance and important level of all the indicators, and then the result the meeting were shared with everyone respondent to get a consensus on priority indicator in assesing core product. Result of the experts judgement on weight value of each indicator presented on Figure 2. 
Figure. 2. Indicator's Value of Core Product Based Experts Judgement

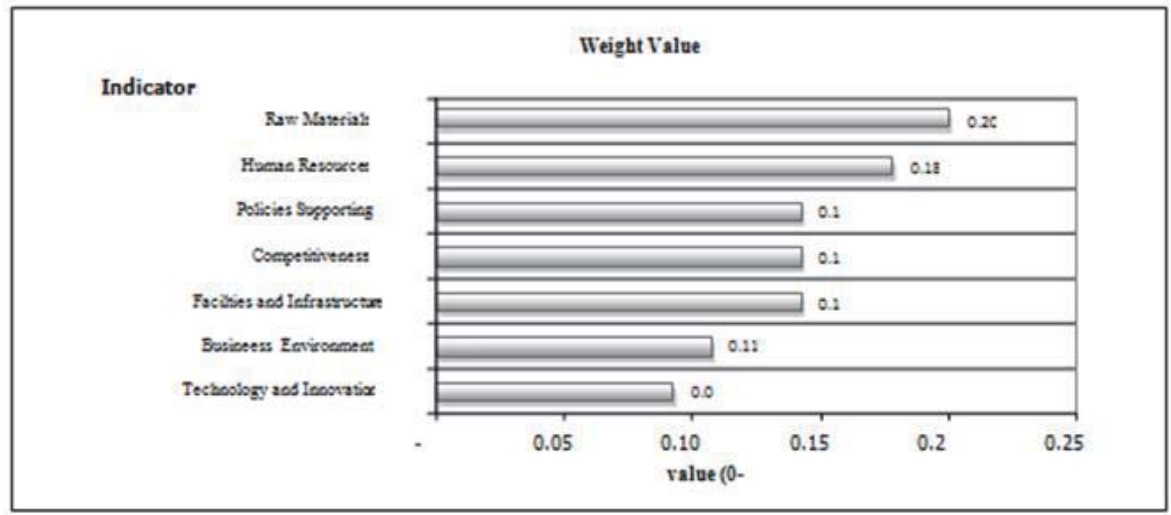

Source: Mappigau and Maupa (2012)

From Figure 2, indicators of core product which assisted by the experts as a good (important) indicator are raw materials with weight value human resource $0: 20$ and human resource with weight value 0.18 , and then, followed by policies supporting, competitiveness, facilities and infrastructure with respective weight value 0.14 and business environment with weight value 0:11; while technology and innovation with weight value of 0.09 are considered as a bad (unimportant) indicators and it's need to be repaired. On the other hand, the indicators value which assisted by entrepreneurs presented on Table. 1. From Table 1, there are three indicators are assisted as bad (unimportant) indicator with a value below the average weight value (1.75 to 2.49) and it's need to be repaired, namely human resource (2.27), competitiveness (2.20), and technology and innovation. Indicators are considered good (important) was business environment (3.94) and facilities and infrastructure $(3,19)$.

Expected value comparison between the five superior product (Table 1), it can be seen that the cowhide leather product has the highest value (3.18) and then respectively followed noodle product (2.73), passion fruit Juice product (2.63), frozen shrimp and fish product (2.50), and furniture product (2.49). Therefore, the cowhide leather product is established by the entrepreneurs as a core product of SSIs in the Makassar city. The highest value of cowhide leather product mainly due to be supported by indicators of business environment condition (4:00), policies supporting (3.87), and facilities and infrastructure (3.76) that categorized as a good indicator. Even the cowhide leather product has highest value, however, it's also still have some indicators are categorized bad (below average) and need to be repaired, namely human resources (2:37) and technology and innovation (2:35).

Table.1. Comparison Indicators's Value of Five Superior Product Based Entrepreneurs Judgement

\begin{tabular}{lccccc}
\hline & \multicolumn{5}{c}{ Superior Product of SSIs } \\
\cline { 2 - 6 } Indicators & Passion Fruit Juice & Noodle & Cowhide Leather & Furniture & Frozen Shrimp and Fish \\
\hline Raw material & 3.04 & 2.78 & 3.06 & 2.73 & 2.61 \\
Human resource & 2.34 & 2.36 & 2.37 & 2.17 & 2.13 \\
Competitiveness & 2.08 & 2.14 & 3.05 & 1.87 & 1.86 \\
Facilities and infrastructure & 3.02 & 3.05 & 3.76 & 2.99 & 3.14 \\
Technology and Innovation & 1.87 & 2.98 & 2.35 & 1.74 & 1.74 \\
Policies Supporting & 2.00 & 2.28 & 3.87 & 2.2 & 2.17 \\
Business environment & 4.00 & 3.97 & 4.00 & 3.77 & 3.95 \\
Expected Value (EV) & 2.63 & 2.73 & 3.18 & 2.49 & 2.50 \\
\hline
\end{tabular}

Note : Good (EV > 3,25), Average (EV: 2,50 - 3,25), Below Average (EV: 1,75 - 2,49), Poor $(E C<1,75)$

Source: Mappigau and Maupa (2012)

Within the case study above, it is apparent that there are differences in perception of the experts and entrepreneurs of SSIs related with their assisted on the important indicator for establishing the core product. To overcome the difference, the first FGD with the targets group undertaken. By using scoring methods to the indicators are used in the TEV analysis 
with the addition of new indicators related to agro-based Industries (viz value added, upstream and downstream integrations) and regional development (viz inter-regional integrations); groups participant considered that the highest rank value is passion fruit juice product (78 \%) and then followed by cowhide leather product (62 \%), and the lowest rank value is furniture product (44\%). Hence, groups of participant established that the passion fruit juice product as core product of the SSIs in Makassar City (see Table 2). The establishment of core product is based on the number of arguments, namely (a) passion fruit juice product enable to value creation in end products; (b) passion fruit juice product already famous both at home and abroad and its market demand is very high, (c) passion fruit juice product has existed for a longtime and its processing industry supported by availability of raw passion fruit. Therefore, it appears that the core product of SSIs in Makassar City is as a resource-based industry. The resource-based industry its means that the core product determined by specific passion fruit. In this case, the core product is the result of SSIs' resources and capabilities to exploit and put the specific passion fruit in a productive use, and shape it into passion fruit juice product as a core benefits provided to consumers. This core product directly related to its core competencies, because of core products are physical embodiment of core competencies (Prahalad and Hamel, 1990) or they are tangible link between identified core competencies and end products (Cyrus and Moghaddam, 2011)

Table. 2. Validation Case Study and Determination Core Product of SSIs In Makassar City

\begin{tabular}{|c|c|c|c|c|c|}
\hline \multirow{2}{*}{ Assessment Criteria } & \multicolumn{5}{|c|}{ Superior Product of SSIs } \\
\hline & Passion /Marquisa Fruit Juice & Noodle & Cowhide leather & Furniture & Frozen Shrimp and Fish \\
\hline Raw material & 4 & 2 & 4 & 3 & 2 \\
\hline Technology and Innovation & 3 & 2 & 2 & 2 & 3 \\
\hline Value added & 3 & 3 & 2 & 2 & 3 \\
\hline Human resources & 4 & 3 & 1 & 2 & 4 \\
\hline Competitiveness & 5 & 2 & 4 & 2 & 3 \\
\hline Facilities and Infrastructure & 3 & 3 & 4 & 3 & 3 \\
\hline Policies support & 3 & 3 & 4 & 2 & 3 \\
\hline Business environment & 4 & 4 & 2 & 3 & 3 \\
\hline Inter-regional integrations & 5 & 3 & 4 & 2 & 2 \\
\hline $\begin{array}{l}\text { Upstream and downstream } \\
\text { integrations }\end{array}$ & 5 & 3 & 4 & 1 & 1 \\
\hline Total & 39 & 28 & 31 & 22 & 27 \\
\hline$\%$ To maximum value & 78 & 56 & 62 & 44 & 54 \\
\hline Priority Rank & 1 & III & II & $\mathrm{V}$ & IV \\
\hline
\end{tabular}

Note: (1) Perception of groups participant is measured based on scale $5 ; 1=$ very low; $2=$ low; $3=$ average; $4=$ high; and $5=$ very high;

(2) Maximum value is 50 (10 main indicators, each indicator's maximum value is 5)

(3) $\%$ to Maximum value = perception value total/ maximum value is multiplied $100 \%$

Source: Mappigau and Maupa (2012)

Furthermore, the second FGD conducted to identify core competence of the core product through value chain activities analysis. Procedure and the result of identification of the core competence by groups participant described as shown in Figure 2. From Figure 2, it is known that groups participant identified the core competence is in operation activity, where specific passion fruit produced by farmers combined with knowledge and skills in processing technique owned by SSIs entrepreneurs, to create and maintain a core competensi in the form of distinctive aroma and flavor and medical content. This result supported by Zack (1999) who stated that core competence is created by integrating knowledge and ability of a company or industry to process valuable resources in new and distinctive ways, to create and provide product for their customers than can their competitors. From previous research, Jardon and Martos (2010) who studied core competence of SMEs in Spain and found that company use combination of resources and capabilities taking into account external factors related to the activity in order to generate core competencies 
Figure. 2. Procedures of Identification and Determination The Core Competence

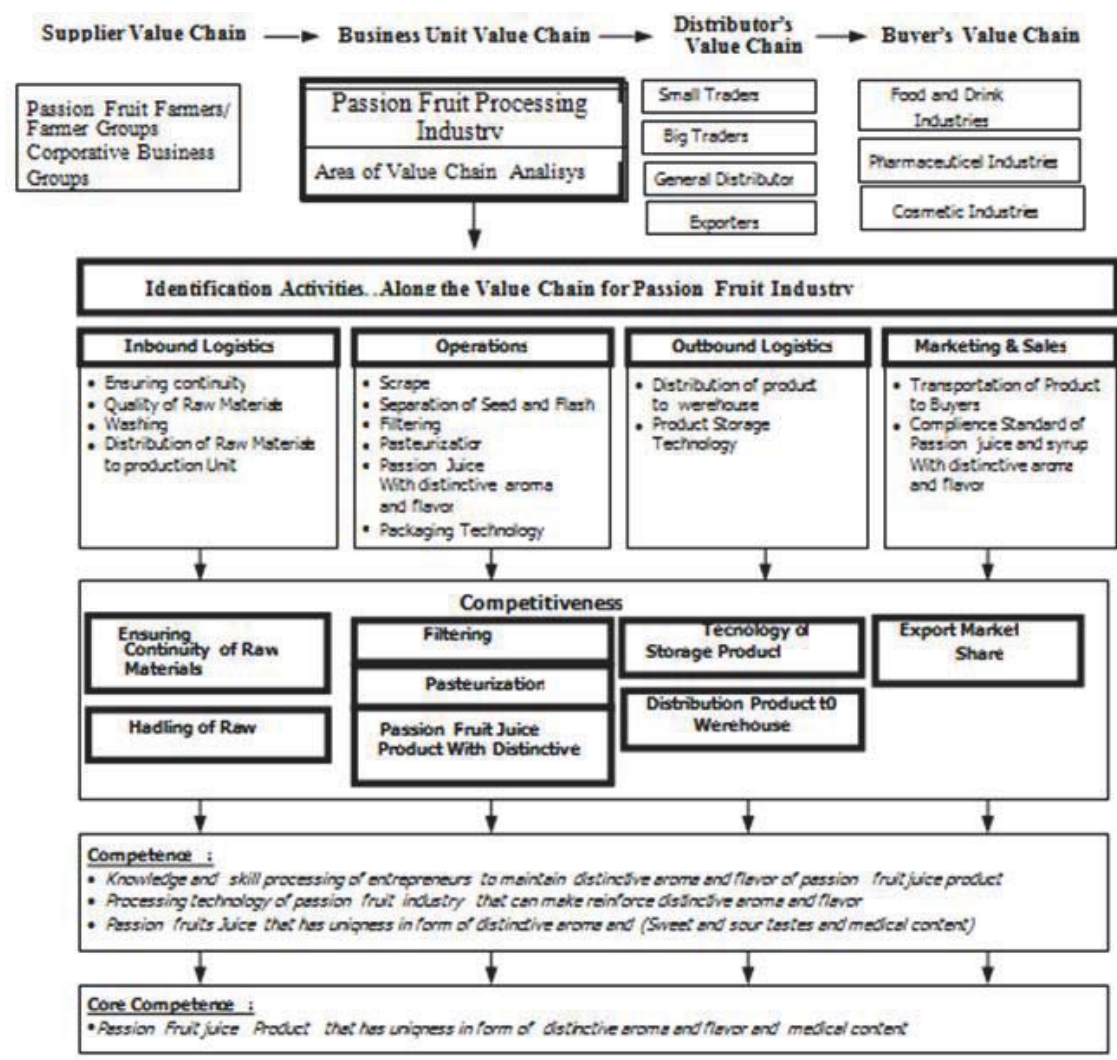

Source: Mappigau and Maupa (2012)

To decide the core competence, the groups participant used several test criteria, namely (1) the core competence has a uniqueness and difficulty to be imitated by rivals in other regions, (2) the core competence can be developed in a larger number of end-user product such as traditional herbal medicine, passion chocolate cake and ingredients in yogurt, jelly, and any other products; (2) the core competence gives social economy benefit in absorb labors, improve farmer's income or other sector labors. (3) the core competence can encourage other sectors, such as passion fruit farming, machine and tools industries, transportation, education and training, banking, food industries, marketing services, etc. The test criteria was consistent with to be suggested by Prahalad and Hamel (1990) who mentioned that to decide whether something is a core competence or not, three tests are applied. First, a core competence provides potential access to a variety of markets. Second, a core competence make contribution much to the perceived customer benefits of the end product. Third, a core competence is difficult for competitors to imitate because it is a complex harmonization of each technology and production skills. The criteria to decide the core competence supported by Pechlaner and Bachinger (2014) who argues that the key to SSIs success is to develop a set of core competencies, which are valuable, rare and transferable to several markets. Turok (2009) suggested that there is a good case for cities to give priority attention to the core competence of industrial sectors in seeking to rebuild a durable economic base, since this is where the indirect and induced multiplier effects are likely to be greatest. By progressively skewing them towards high end user products and services, the argument is that cities can increase local productivity and average incomes.

After core competence identified, and then, the groups participant employed analysis of regional core competence to decide whether the core competence of the core product can used as a regional core competence of the Makassar city. Based on the results of analysis, the group participant decided by consensus that the core competence of the core product (passion fruit juice product) is feasible to become a regional core competence of Makassar City. This result supported by Ljungquist (2012) who argued that the regional core competence (product) is often claimed to be a stepping-stone to the future success of the regional development. Furthermore, Pechlaner and Bachinger (2014) point out that the regional core competence is able to foster regional development and keeping a competitive region over a long period, because of the regional core competence is as a promoter of entrepreneurship. Papula et al. (2013) also 
confirmed that building-up core competence through SSis are generally the driving force of regional economic development, are developing options for future competitiveness in the form of new knowledge, and are increasing the efficiency of the regional economy and its ability to act.

Strategy for formulating the development of regional core competence of Makassar City designed in the second FGD using SWOT analysis. From result of the SWOT analysis, groups participant recommended several priorities of selected strategies, such as: (1) developing human resources abilities of the entrepreneurs to innovate in the technical and management aspects, (2) building information and knowledge sharing between the entrepreneurs with farmers and traders to integrate activities and processes of the core product that together supply chain to deliver customer value, (3) building cooperation with universities and centers of research in order to develop innovation of the regional core competence and end user product; (4) improving a business environment that is conducive to growth and competitiveness the SSIs, including incentives for advanced processing techniques

\section{Conclusion and Recommendation}

The key findings from this study are: firstly, based on result of the case study and then it validated by groups participant in the forum group discussion (FGD) suggests that passion fruit juice product established as core product of the SSIs in Makassar City. Second, result of value chain activity analysis on the core product, groups participant finding that core competence is on operations activities, viz distinctive aroma and flavor and medical content. Third, result of regional core competence analysis, the groups participant agreed that the core competence is feasible to become regional core competence of Makassar City. Fourth, result of SWOT analysis, the groups participant recommended several priorities of selected strategies, such as : (1) developing human resources abilities of farmers and entrepreneurs to innovate in the technical and management aspects, (2) building sharing information and knowledge between the entrepreneurs with the farmers and traders to integrate activities and processes of core product supply chain that together to deliver customer value, (3) building cooperation with universities and centers of research in order to develop innovation of the regional core competence and end user product; (4) improving a business environment that is conducive to SSIs growth and competitiveness, including incentives for advanced processing techniques.

We believe that these findings make important contribution to the body literature on core competence and regional development by providing practical methods to apply core competencies concept in SSIs for regional core competence. For practical implications, these findings should be helps the entrepreneurs of SSis to utilize their core competences in order to improve their competitive advantage (e.g. gain market share and profit). This finding also can become a reference for the Makassar City government in policy formulation regarding SSIs which will be developed in order to use of local resources and capabilities optimally so that the SSIs can contribute significantly to region's economy and competitiveness. For social implication, the existence of regional core competence in turn will help to overcome the problem of unemployment and poverty in the Makassar City.

\section{Limitation}

Limitation of this study is we didn't analyze role of core competence to failure or success of SSIs in a region and further its impact to a regional competitiveness. Therefore, for further research suggested any similar study in other city to examine effect of core competence to failure or success of SSIs in a region and then examine its impact on regional competitiveness. In addition, it is also suggested any similar study and in dept analysis that focusing a villages region with regard to industrial village development, since SSIs are concentrated not only in urban areas but also in villages area

\section{Acknowledgements}

We are very grateful to the PT. Rensa Kerta Mukti for funding this research works. We also acknowledge to all stakeholders who participated in doing research and writing this article, and who provided comments and suggestions for improvement of this article at the 28th International Business Research Conference held in Barcelona, Spain on 8 - 9 September, 2014

\section{References}

Andriessen, D., Frijlink, M., Gisbergen, I van., Blom, J. (2000), A core competency approach to valuing intangible assets". Paper presented at the International Symposium Measuring and Reporting Intellectual Capital: Experiences, Issues, and Prospects, OECD, June 2000, 
Amsterdam.

Benavides, L,(1992). Hazardous waste management for small-scale and cottage industries in developing countries: Overview. Expert Group Meeting on Local Management of Hazardous Wastes From Small-Scale and Cottage Industries. Nairobi: HABITAT, Urban Management Programme.

Boddy, M., Hudson, J., Plumridge, A. and Webber, D.J, (2007 ). Explaining spatial variation in business performance in Great Britain, The European Journal of Comparative Economics, 4 (2), pp. 319-332.

Constantin, D.L. (2002). SMEs, Territorial development and networking: The case of Romania, The 42nd congress of the European Regional Science Association, August 27-31, 2002, Dortmundt

Cyrus, K. M and Moghaddam, M.R. (2011). Core competency (a new model), World Academy of Science, Engineering and Technology, 5, pp. 279-285.

Djamaris, A. (2007). Analysis regional core competence, Oct. 2007, URL : aurino.com/../fr/keunggulan-berbasis-kompetensi/

Garden, C. and Martin, R.L. (2005). A Study on the factors of regional competitiveness: A draft final report for the European Commission Directorate-General Regional Policy, URL: http://ec.europa.eu/regional_policy/sources/docgener/studies/pdf/3cr/ competitiveness.pdf.

Ghannad, N and Ljungquist, U. (2012). Change of entrepreneurial agenda in a core competence context: exploring the transformation from technology focus to market focus, Int. J. Entrepreneurial Venturing, 4 (2), pp. 148-167.

Hussain, S.V. (2003). Small Scale Industries in the new millenium, Sarup Publication, New Delhi, India.

Industryl and Trade Department of Makassaar City. (2012). Makassar City in Figure 2012, The Central Bureau Statistics of Makassar City.

Jardon, C. M. F and Martos, M.S. (2010). Determination of distinctive competencies in SMES: The Case of Vigo and its Area of Influence (Spain), Visión de Futuro" Año 7, №2 Volumen N014, URL : www.fce.unam.edu.ar/revistacientifical

Jardon, C. M. F. (2011). Deployment of core competencies to obtain success in SMEs, Working Paper: 11/06. December 2011, Departamento de Economía Aplicada, Universidad de Vigo, Spain.

Kostopoulos,K., Papalexandris, A., Papachroni,M and loannou, G. (2011). Absorptive capacity, innovation, and financial performance, Journal of Business Research, 64, pp. 1335-1343.

Lai-Yu, T.F. (2001). Toward a capabilities perspective of the small firms. International Journal of Management Reviews. 3 ( 3), pp. 185-97.

Laosirihongthong,T., Chun Hsu, C., Choon Tan, K and Keong Leong,G. (2011). Asean automotive supply chain management (SCM): entrepreneurial scm competence and performance, The 11th International DSI and the 16th APDSI Joint Meeting, Taipei, Taiwan, July 12 $-16,2011$

Liu, B., Hu, J and Tian, M. (2012). Research on the core Competence and sustainable development of small and,medium-sized enterprises, 2012 2nd International Conference on Industrial Technology and Management (ICITM 2012, IPCSIT, Vol. 49 (2012), pp.229-232. ACSIT Press, Singapore.

Ljungquist, U. (2012). New dimensions added for enhanced core competence application, CSIR Electronic Working Paper Series Paper No. 2012/ 3 February 2012 Center for Strategic Innovation Studies (CSIR) Blekinge Institute of Technology, URL : http://www.bth.se/csir

Mansour Hefnawy A.A. S. (2006). The role of small manufacturing enterprises in sustainable rehional development, Ismailia governorate as a case study in Egypt, Dissertation, Tchnische Universitat Dresden 2006.

Mappigau, P and Maupa, H. (2012). Study of the industry's core competencies development in Makassar City, PT. Rensa Kerta Mukti, Department of Industry, Jakarta

Ministry of industry. (2010). Map guide (road map) development of industrial regional core competence, March 2010, URL : www.kemenperin.go.id/.../Peta-Panduan-(Road-Map)-...

Min Wu, C., Lin Hsieh,C and Lun Chang, K. (2013). A hybrid multiple criteria decision making model for supplier selection, Mathematical Problems in Engineering Volume 2013,pp. 1-8.

Mitrut, C and Constantin, D.L. (2006). Current issues ccncerning regional policy and SMEs in Romaniall, in SouthEastern Journal of Economics, 4 (2), pp. 209-222.

Naylor, R. J. (2001). Core competencies what they are and how to use them. Paper presented at 2nd Annual Institute on 21st Century Librarianship. Standford University.

Papula, J., Volná, J. and Hul've, J. (2013). Knowledge networks as a source of knowledge initiatives and innovation activity in small and medium enterprises, Proceedings of International Conference KDIR 2013 and KMIS 2013 Algarve: Scitepress, pp. 389-396.

Pechlaner, H. and Bachinger, M. (2014). Regional core competencies as a basis for entrepreneurship? The German hop-growing area of the Hallertau, Entrepreneurship and Innovation, 15 (1) ,pp. 41-50.

Porter, M.(1979). How competitive forces shape strategy. Harvard Business Review, 57(2), pp.137-145.

Porter, M. 1990. The competitive advantage of nations, The Free Press. New York

Porter, M.(2011) Creating shared value, Harvard Business Review, 89 (1/2), pp. 62-77.

Prahalad C.K. and G. Hamel. (1990) The core competence of the corporation, Harvard Business Review, 68 (30), pp.79-92.

Shihabudheen N. (2013) Role MSME Act 2006 in promoting SSIs in Malappuram: An empirical study of Manjeri Municipality, Kerala, India International Research Journal of Social Sciences, 2 (9), pp. 11-18.

Srivastava, S.(2005) Managing core competence of the organization. Vikalpa,30 (4), pp. 49-68.

Suharso, P. (2008). Quantitative model analysis (TEV), Published Int. Jakarta

Stoner, C.R. (1987), Distinctive competitive and competitive advantage, Journal of Small Business Management, 25(2), pp.33-39.

Sweeney, M.T. (1994). Benchmarking for strategic manufacturing management. International Journal of Operations \& Production Management, 4 (9), pp. 4-15.

Torkkeli, M. and Markku, T. (2002), The contribution of technology selection to core competencies, International Journal of Production Economics, 77, pp.271-284.

Turok, T. (2009). The distinctive city: pitfalls in the pursuit of differential advantage, Environment and Planning, 41, pp. 13-30.

Yamoah, E.E. (2013). Distinctive competency and its implication to marketers in Ghana, British Journal of Marketing, 1(4), pp. 29-31.

Zack, M.H. (1999). Developing a knowledge strategy, California Management Review,41(3), pp. 125-145. 